\title{
Symbolic Power in European Diplomacy: The Struggle Between National Foreign Services and the EU's External Action Service
}

Adler-Nissen, Rebecca

Published in:

Review of International Studies

DOI:

$/ 10.1017 / \mathrm{S} 0260210513000326$

Publication date:

2014

Document version

Early version, also known as pre-print

Citation for published version (APA):

Adler-Nissen, R. (2014). Symbolic Power in European Diplomacy: The Struggle Between National Foreign Services and the EU's External Action Service. Review of International Studies, 40(4), 657-681.

https://doi.org//10.1017/S0260210513000326 


\section{Review of International Studies}

http://journals.cambridge.org/RIS

Additional services for Review of International Studies:

Email alerts: $\underline{\text { Click here }}$

Subscriptions: Click here

Commercial reprints: Click here

Terms of use : Click here

\section{Symbolic power in European diplomacy: the struggle between national foreign services and the EU's External Action Service}

Rebecca Adler-Nissen

Review of International Studies / FirstView Article / October 2013, pp 1 - 25

DOI: 10.1017/S0260210513000326, Published online: 28 October 2013

Link to this article: http://journals.cambridge.org/abstract S0260210513000326

How to cite this article:

Rebecca Adler-Nissen Symbolic power in European diplomacy: the struggle between national foreign services and the EU's External Action Service. Review of International Studies, Available on CJO 2013 doi:10.1017/S0260210513000326

Request Permissions : $\underline{\text { Click here }}$ 


\title{
Symbolic power in European diplomacy: the struggle between national foreign services and the EU's External Action Service
}

\author{
REBECCA ADLER-NISSEN*
}

\begin{abstract}
National diplomacy is challenged by the rise of non-state actors from transnational companies to non-governmental organisations. In trying to explain these challenges, scholars tend to either focus on a specific new actor or argue that states will remain the dominant diplomatic players. This article develops an alternative Bourdieu-inspired framework addressing symbolic power. It conceptualises diplomacy in terms of a social field with agents (field incumbents and newcomers alike) who co-construct and reproduce the field by struggling for dominant positions. The framework is applied to the EU's new diplomatic service (the European External Action Service, EEAS), which is one of the most important foreign policy inventions in Europe to date. I show that the EEAS does not challenge national diplomacy in a material sense - but at a symbolic level. The EEAS questions the state's meta-capital, that is, its monopoly of symbolic power and this explains the counter-strategies adopted by national foreign services. The struggles to define the 'genuine' diplomat reveal a rupture in the European diplomatic field, pointing towards a transformation of European statehood and the emergence of a hybrid form of diplomacy. A focus on symbolic power opens up new avenues for the study of transformations of authority in world politics.
\end{abstract}

Rebecca Adler-Nissen is Associate Professor in the Department of Political Science at the University of Copenhagen. Previously she has worked as Head of Section in the Danish Ministry for Foreign Affairs. Her research focuses on international political sociology, diplomacy, sovereignty, and European integration. She is editor of Bourdieu in International Relations: Rethinking Key Concepts in IR (Routledge, 2012) and author of Opting Out of the European Union: Diplomacy, Sovereignty and European Integration (Cambridge University Press, 2014).

\section{Introduction}

The rise of non-state actors on the global scene appears to transform diplomacy. These new actors, ranging from transnational companies to global media, over nongovernmental organisations to multilateral organisations, challenge the image of

\footnotetext{
* I wish to thank the editors, the four anonymous reviewers, and Graham Avery, Jozef Bátora, Costas Constantinou, Noe Cornago, Gunther Hellman, Niilo Kauppi, Mikael Rask Madsen, Dorte Martinsen, Ian Manners, Peter Nedergaard, Iver B. Neumann, Lene Hansen, Ben Rosamond, David Spence, Morten Holm-Hemmingsen, and Annika Bergman Rosamond, for their helpful comments. I owe great thanks to Fabrice Jacobsen and Ida Malou Jensen for assistance with the data collection. Moreover, I am grateful to employees at the EEAS and the Danish, French, Polish, and German Ministries of Foreign Affairs. Last but not least, I wish to thank my colleagues for sharing their thoughts and experiences with me while I was working as a Head of Section in the Danish Ministry of Foreign Affairs (September 2010-September 2011). I am of course solely responsible for any mistakes in this article.
} 
national diplomats as 'custodians of the idea of international society'. ${ }^{1}$ Also domestically, national foreign services (in most Western countries) are under pressure from increased and more autonomous international activities by other ministries and a greater concentration of foreign policy activities around prime ministers and presidents, thereby side-lining the foreign ministries themselves. Symbolically, new articulations of collective representation, differing from the traditional promotion of national interests, such as the 'No Logo' movement, the Seattle demonstrations, and various attempts to create a transnational public sphere challenge territorial-based diplomacy. ${ }^{2}$

This article examines one of the most important foreign policy inventions in Europe to date: a diplomatic service of the European Union. The creation of a High Representative for Foreign and Security Policy and an External Action Service (EEAS), as it is officially called, remains one of the Treaty of Lisbon's controversial inventions. Since 1 December 2010, the EEAS has been given the task to serve the EU's common foreign policy, represent the European Union (EU) around the world, and develop common strategies on everything from EU peacekeeping missions to humanitarian aid ${ }^{3}$ and possibly consular affairs for EU citizens abroad. ${ }^{4}$ This new diplomatic body will bring together - for the first time - national diplomats, civil servants from the Commission, and officials from the Council secretariat under the same roof. The EEAS currently only employs about 3,400 people and is thus comparable in size to the foreign service of a medium-size member state. Yet the creation of a fully integrated European foreign service has been met with anxieties by observers in the EU member states, fearing that it will eventually undermine national diplomacy. As Finnish Foreign Minister Alexander Stubb puts it, '[a] lot of us [foreign ministers] are going through a bit of an existential crisis' because of the Union's new institutions. ${ }^{5}$ However, decisions on EU foreign policy are still taken unanimously, and Europe remains divided over important foreign policy issues. How can such a small organisation - with a Brussels headquarters under construction and understaffed delegations in third countries - be so anxiety-provoking in Europe?

Studies of diplomacy and EU foreign policy have tended to focus on institutional or material changes and have ignored or downplayed the symbolic changes that are also in progress. Thus, the EU's new diplomatic service is either judged by its potential administrative capacity or by estimations of the (lack of) military capabilities that the member states are willing to endow it with. International Relations (IR) realists have regarded the EU's foreign policy as 'naïve' or even 'tragic' due to the EU's lack of military strength. ${ }^{6}$ Constructivists have seen the EU as representing a 'normative power', ${ }^{7}$ but fail to address the crucial relationship between the EU and

1 H. Bull, The Anarchical Society (Houndsmills: Palgrave, 1977), p. 176.

2 C. M. Constantinou and J. Der Derian, 'Introduction', in C. M. Constantinou and J. Der Derian (eds), Sustainable Diplomacies (New York: Palgrave Macmillan, 2010); J. C. Alexander, "Globalization" as Collective Representation: The New Dream of a Cosmopolitan Civil Sphere', International Journal of Politics, Culture, and Society, 19:1-2 (2005), pp. 81-90.

3 EuopeAid is still under the control of the Commission.

4 TEU art. 10A.

5 K. Radtke, 'The EU's Common Foreign and Security Policy (CFSP) after the Lisbon Treaty: Supranational Revolution or Adherence to Intergovernmental Pattern?', in F. Laursen (eds), The EU's Lisbon Treaty: Institutional Choices and Implementation (Farnham: Ashgate, 2012), p. 163.

6 J. Mearsheimer, 'A Realist Reply', International Security, 20:1 (1995), pp. 82-93; A. Hyde-Price, 'A "tragic actor"? A realist perspective on "ethical power Europe",, International Affairs, 84 (2008), pp. 29-44.

7 I. Manners, 'Normative Power Europe: A Contradiction in Terms?', Journal of Common Market Studies, 40:2 (2002), pp. 235-58. 
national foreign services. While some observers see the EEAS as finally providing the EU with the single telephone number that Henry Kissinger (mythically) asked for in the $1970 \mathrm{~s},{ }^{8}$ critics would point to the continuation of institutional turf-wars. ${ }^{9}$ These perspectives differ in their fundamental assumptions about what drives international politics and more specifically about the nature of the EEAS, but they are all based on the assumption that material or institutional resources are decisive for international politics. Few scholars discuss the symbolic struggles involved in the establishment of this new diplomatic body and their effects on the European diplomacy and sovereignty. ${ }^{10}$

This article presents both a negative and a positive thesis. It shows that the material and institutional dimensions (for example, human resources and legal competences) of the EU's new diplomatic service have been vastly exaggerated by its critics. Why is the EEAS then met with such anxiety? The positive thesis is an answer to this question. I argue that, just as the material and institutional dimensions have been exaggerated, both critics and supporters have underestimated the symbolic struggles over the EEAS, which concern the role of the state in diplomacy.

This article develops a Bourdieu-inspired framework conceptualising a European diplomatic field, that is, a structured social space, where different state- and non-state actors struggle for dominant positions. In this space, national diplomats have achieved a dominant position due to the state's symbolic power. The framework is used to analyse, first, the constitutional struggle to establish new diplomatic body, focusing on the treaty negotiations in 2002-3, including whether the head of the EEAS should be called 'Union Minister for Foreign Affairs'. Second, I examine the relative positions and capital of the EEAS and the national foreign services as well as their struggle to define the 'genuine' diplomat, illustrated by the disputes over appointment of Heads of Delegations and consular affairs. Third, I zoom in on recruitment and position-takings of three subgroups: seconded national diplomats, civil servants from the European Commission, and officials from the Council secretariat - who, together, may effectively construct a diplomatic ésprit de corps. The analysis demonstrates that the EEAS is not just innovating or supplementing (as other new diplomatic actors) but potentially subversive. The EEAS questions the state as 'a central bank for symbolic credit', meaning its monopoly on symbolic power. This explains its controversial nature and the counter-strategies adopted by national foreign services and domestic constituencies to delegitimise the EEAS. From this perspective, 'Ashtonbashing' is not just a question of personality, but also an instance of hysteresis, that is, the lack of adjustment between field and habitus. The struggles to define the 'genuine' diplomat reveal a rupture in the European diplomatic field, pointing towards the emergence of a hybrid form of diplomacy. The concluding section discusses how an

8 For a discussion of the Kissinger telephone myth, see C. Bickerton, 'Towards a Social Theory of EU Foreign and Security Policy', Journal of Common Market Studies, 49:1 (2011), pp. 171-90.

9 S. Stetter, 'Cross-Pillar Politics: Functional Unity and Institutional Fragmentation of EU Foreign Policies', Journal of European Public Policy, 4:11 (2004), pp. 720-39; M. E. Smith, Europe's Foreign and Security Policy: The Institutionalization of Cooperation (New York: Cambridge University Press, 2004); J. Bátora, 'Does the European Union Transform the Institution of Diplomacy?', Journal of European Public Policy, 1:12 (2005), pp. 44-66; T. Diez, I. Manners, and R. Whitman, 'The Changing Nature of International Institutions in Europe: The Challenge of the European Union', Journal of European Integration, 33:2 (2011), pp. 117-38.

10 But see F. Mérand, European Defence Policy Beyond the Nation State (Oxford: Oxford University Press, 2010). 
analysis of symbolic power and social fields provides new avenues for examining authority, power, and practice in international relations.

\section{A political sociology of symbolic power}

That most scholars neglect symbolic power as a central dynamic in diplomacy is not surprising given that diplomacy has remained largely understudied from a sociological perspective. ${ }^{11}$ Traditional definitions of diplomacy highlight 'the process of dialogue and negotiation by which states in a system conduct their relations and pursue their purposes by means short of war', establishing a tight linkage between diplomacy and state institutions. ${ }^{12}$ Such definitions are not wrong, but they are incomplete. For instance, although the English School has a long tradition of thinking about diplomatic culture, it fails to fully acknowledge diplomacy as 'a form of knowledge production'. ${ }^{13}$ Moreover, traditional approaches overlook that the state's capacity to carry out its diplomatic functions hinges in crucial respects on its exercise of symbolic power. More recently, sociologically oriented IR scholars have fruitfully used Bourdieusian concepts to highlight diplomacy as a symbolic practice. ${ }^{14}$ Drawing on these studies, this section develops a Bourdieu-inspired approach, which can help explain why the EEAS is met with such anxiety and what it does to European diplomacy.

\section{The field as a social space of struggles}

A field, according to Bourdieu, is a structured space of social relations, centred on agreed-upon stakes, functioning according to known, if often implicit rules, wherein actors draw on their capital as a resource to maintain or improve their position in the field. ${ }^{15}$ The stratification of a field is based on different forms of capital (for example, economic, social, and cultural capital) and the efficacy of the capital depends on the contexts where it is used. Capital in this sense is a form of power resource, which is as much symbolic as it is material. Each field has a particular mix of relevant capital, and power cannot be imported easily into a new field. There are a multiple of different fields (the academic field, the artistic field, and the political field) where different practices take place. ${ }^{16}$ The boundaries of the field, and the definition of who populates the field, are a matter of constant struggle, specifically a by-product of attempts to establish legitimate domination within the field. Struggles involve legitimising the stakes themselves, thereby establishing what sorts of capital holdings have what degree of value.

\footnotetext{
11 For important and valuable exceptions, see I. B. Neumann, " 'A Speech That the Entire Ministry May Stand for", or: Why Diplomats Never Produce Anything New', International Political Sociology, 2:1 (2007), pp. 183200; I. B. Neumann and H. Leira, Aktiv og avventende: Utenrikstjenestens liv 19052005 (Oslo: Pax Forlag, 2005); I. B. Neumann, At Home with the Diplomats: Inside a European Foreign Ministry (Cornell University Press, 2011).

12 A. Watson, Diplomacy: The Dialogue Between States (London: Eyre Methuen, 1982), p. 10.

13 I. B. Neumann, At Home with the Diplomats, p. 7.

14 See, for example, F. Mérand, European Defence Policy; I. B. Neumann and V. Pouliot, 'Untimely Russia: Hysteresis in Russian-Western Relations over the Past Millennium', Security Studies, 20:1 (2011), pp. $105-37$

15 F. Mérand European Defence Policy, p. 6.

16 P. Bourdieu, Language and Symbolic Power (Cambridge: Polity, 1992), p. 229.
} 
The dynamics of a field arise from the positions, dispositions and position-takings of agents, which produce habitus. Bourdieu sees habitus as a system of durable dispositions that make individuals act, perceive, and think in a particular way and in accordance with the field throughout time. ${ }^{17}$ Thus an agent whose habitus is perfectly adapted to the field possesses a sens pratique, a 'feel for the game'. ${ }^{18}$ There is a clear link between the field-prescribed habitus and field incumbents' expectations that newcomers should conform to current field arrangements. ${ }^{19}$

When newcomers enter a field or agents move across a field, we may see a hysteresis effect, that is a 'mismatch between the dispositions agents embody and the positions they occupy in a given social configuration'. ${ }^{20}$ As Neumann and Pouliot note, hysterestetic practices are not 'objectively' maladjusted, they are so 'from the perspective of dominant agents within the social field'. ${ }^{21}$ Newcomers entering a field may lead dominant agents to embark on negative sanctions. Yet habitus does not preclude newcomers from acting artfully and improvising and it does not prevent incumbents to respond to new experiences. In fact, dispositions are subject to permanent revision.

\section{The state and its symbolic power}

The fact that the state diplomat is now the dominant figure in diplomacy hinges on what Bourdieu termed symbolic power. ${ }^{22}$ It is the imposition of particular perceptions upon social agents who then take the social order to be just. In some senses, symbolic power is much more powerful than physical power in that it is embedded in citizens' modes of action and structures of cognition, imposing a sense of legitimacy onto the existing social order. Symbolic power does not operate on the level of conscious intentions. It refers to power dynamics that are not based on (rationalcalculated) interests. Indeed, 'its tacit character implies that it can only function with the complicity of the dominated and even those who do not know that they practice it'. ${ }^{23}$

To Bourdieu, the particularity of the state as an organisation, born by and geared for power concentration, is not material. The specificity of the state is not the accumulation of legitimate physical violence (as Weber would have it), but the monopolisation of legitimate symbolic power. ${ }^{24}$ The state is first and foremost 'a central bank for symbolic credit', which makes social division, privileges, and domination universally valid within a given territory and for a given population. ${ }^{25}$ If there is no state or the state is essentially contested, the state cannot produce this symbolic power (for

17 P. Bourdieu, Raisons practiques. Sur la théorie de la raison (Paris: Éditions du Seuil, 1994), p. 163.

18 P. Bourdieu, Raisons practiques.

19 D. De Clerq and M. Voronov, 'The Role of Domination in Newcomers' Legitimation as Entrepreneurs', Organization, 16:6 (2009), p. 804.

20 I. B. Neumann and V. Pouliot, 'Untimely Russia', p. 105.

21 Ibid., 'Untimely Russia', p. 111.

22 P. Bourdieu, Language and Symbolic Power, for an interesting analysis of symbolic power in international trade politics, see M. Eagleton-Pierce, Symbolic Power in the World Trade Organization (Oxford: Oxford University Press, 2013).

23 K. Stuvøy, 'Symbolic Power and (In)Security: The Marginalization of Women's Security in Northwest Russia', International Political Sociology, 4:4 (2010), p. 403.

24 P. Bourdieu, 'Social Space and Symbolic Power', Sociological Theory, 7:1 (1989), p. 21.

25 P. Bourdieu, La Noblesse d'Etat. 
example, Palestine/Israel, Tibet, Vatican). However, Bourdieu constructed his state theory in a European context and most European states today accumulate this power.

The state is special because it does not compete for the definitions of legal and educational status, because it already has pre-eminence over these areas; it has 'meta-capital'. ${ }^{26}$ This understanding of power links the social construction of knowledge to the construction of social reality. The state, in other words, can exercise 'a power over other species of power ... and particularly over their rate of exchange'. ${ }^{27}$ This means that the state is a reference point in social life, exerting its influence not only in one field, but across all fields. Within each field, holders of different kind of capital compete with each other for the control over state authority.

Moreover, the state is incorporated in its citizens, as Chopra notes:

The state ... shapes structures of perception and cognition across the society that the state governs. This is what Bourdieu means by the phrase 'Minds of State' (1998c: 52), suggesting that the state exists as much an entity 'outside' of its citizens as it exists 'of' the citizens. ${ }^{28}$

This implies that it has become naturalised in the sense that is taken for granted by its citizens.

Importing Bourdieu's theory into IR implies, somewhat paradoxically, that the state is understood in relative terms. The question then becomes how state diplomacy plays out in relation to other articulations of authority. My operationalisation focuses on three dimensions of this struggle: (1) the negotiations and debates concerning the entry of a new actor in the field (constitutional struggle); (2) the relative positions of newcomers and incumbents and their accumulation of diplomatic capital; and (3) the classificatory struggles, dispositions, and position-takings of the newcomers and incumbents.

\begin{tabular}{lll}
\hline & Types of practices & Examples \\
\hline Constitutional struggles & $\begin{array}{l}\text { Struggles over what counts } \\
\text { as legitimate competences } \\
\text { (e.g. the boundaries of the } \\
\text { state's reach). }\end{array}$ & $\begin{array}{l}\text { Treaty negotiations, institu- } \\
\text { tions, formal titles }\end{array}$ \\
$\begin{array}{l}\text { Struggle for diplomatic } \\
\text { Relative positions and } \\
\text { capital accumulation }\end{array}$ & $\begin{array}{l}\text { symbolic), including strug- } \\
\text { gles to reproduce or redefine } \\
\text { what counts as capital }\end{array}$ & \\
& $\begin{array}{l}\text { Naturalisation of categories, } \\
\text { cognitive schemes through } \\
\text { administrative regulation, } \\
\text { codification, routinisation, } \\
\text { dispositions, } \\
\text { and socialisation }\end{array}$ & Training, careers \\
\hline
\end{tabular}

Table 1. The struggle for symbolic power

26 R. Chopra, 'Neoliberalism As Doxa: Bourdieu's Theory of the State and the Contemporary Indian Discourse on Globalization and Liberalization', Cultural Studies, 3/4:17 (2003), p. 429.

27 P. Bourdieu and L. Wacquant, An Invitation to Reflexive Sociology (Chicago: Chicago University Press 1992), p. 114.

28 R. Chopra, 'Neoliberalism As Doxa', p. 430. 
This article cannot do justice to Bourdieu's detailed empirical studies, but it analyses the three dimensions by first examining the treaty negotiations and debate on the formal competences of the EEAS, including whether the head of the EEAS should be called 'Union Minister for Foreign Affairs'. Second, it analyses the struggle for diplomatic capital by examining the material and symbolic resources at play in the staffing and geographical representation of the EEAS and national services respectably. This struggle involves the definition of the 'genuine' diplomat as can be seen in the criticism of the High Representative Catherine Ashton and her appointment of Heads of Delegations. Finally, it zooms in on the dispositions and positiontaking of the three subgroups: seconded national diplomats, civil servants from the European Commission, and officials from the Council secretariat - who, together, become Europe's new diplomats.

The analysis builds on a combination of data: treaty texts, official documents, statements, and speeches by leading decision-makers, newspaper articles, and 15 interviews with EEAS officials (working in Brussels and EU delegations) and officials from the British, Danish, French, German, and Polish foreign services as well as a one year stint in one of the member state's national foreign services (2010-11).

\section{Newcomers in the European diplomatic field}

While the language of diplomacy is rife with references to order, diplomacy is far from a stable phenomenon. For instance, the differentiation between 'domestic' and 'foreign' was only institutionalised in the eighteenth century and distinct foreign ministries only emerged at the end of the eighteenth century. ${ }^{29}$ The field of diplomacy is produced by constant struggles for domination. Today, state agents - and more specifically national foreign services - have acquired a dominant position in what can be conceptualised as the European diplomatic field.

Newcomers, as mentioned above, may threaten the position of incumbents, in this case national diplomatic elites. In Europe and beyond, traditional state-based diplomacy, centred on a foreign minister and a foreign service, is under pressure from many sides. First, non-state actors, from private companies to non-governmental organisations, increasingly engage in their own separate diplomatic activities. ${ }^{30}$ Second, global media, technological developments and increased parliamentary control of foreign policy represent a growing challenge to traditional diplomacy. For instance, new communication technologies allow for a more easy access to information that used to be monopolised by diplomatic circles. Third, the last decades have seen a relative decline of the foreign services vis-à-vis other parts of the state apparatus. ${ }^{31}$ Today, most ministries have their own skilled international secretariats that uphold relations with their peers in other states and they send their own personnel on diplomatic missions. Moreover, in most European states, there is a greater concentration of foreign policy activities around prime ministers and presidents, thereby

29 I. B. Neumann, At Home with the Diplomats, p. 53.

30 A. F. Cooper and B. Hocking, 'Governments, NonGovernmental Organizations and the Recalibration of Diplomacy', Global Society, 14:3 (2000), pp. 361-7.

31 See, for example, D. Spence, 'The Evolving Role of Foreign Ministries in the Conduct of European Union Affairs', in B. Hocking and D. Spence (eds), Foreign Ministries in the European Union: Integrating Diplomats (New York: Palgrave, 2005), pp. 18-36. 
side-lining foreign ministries. Together these tendencies imply that international relations are no longer the exclusive preserve of foreign ministries. ${ }^{32}$

Nonetheless, national diplomats have generally been in a position to rebuff challengers, they have largely been able to affirm their mastery over the art of diplomacy. The practical mastery of the specific knowledge, which is inscribed in past negotiations (treaties), material resources (embassies), institutions (diplomatic immunity), and rituals (presentation of credentials), recorded and canonised by professionals in conversation along with scholars and journalists - has become part of the conditions for a dominant position in the field of diplomacy.

Yet in this process of gate-keeping and rebuffing national diplomats have also transformed their own practice. One example is Europeanisation. ${ }^{33}$ Mérand notes that national diplomats have been 'keen to promote [EU] foreign policy cooperation as a way to protect their turf against the encroachment of specialized ministries' ${ }^{34}$ He adds, 'while most EU policies have been domesticated, European foreign policy is the only competence that remains truly theirs'. ${ }^{35}$ Since the 1970s, the member states have effectively sought to work together through the European Political Cooperation (EPC), the forerunner of the Common Foreign and Security Policy. The EPC, which was kept separate from the European Community (and hence the Commission), led to a proliferation of high-level meetings, working groups, and coordination among diplomats form the member states, discussing a variety of topics from non-proliferation to development issues in Africa. ${ }^{36}$ In 1992, the Maastricht Treaty took major steps to coordinate the foreign policies of the EU member states, creating common mechanisms for pursuing shared interests and defining shared objectives in broad terms. ${ }^{37}$ However, it was only with the Lisbon Treaty (2009) that the EU got its own diplomatic service, separate from national foreign policy systems. In this sense, the EEAS represents a novelty - a quasi-supranational diplomatic corps ${ }^{38}$ - leading to uncertainty about the future of national foreign services.

\section{Constituting the EU's diplomatic service}

Ian Manners claims that the EU is constituted and constitutes itself through symbols and symbolism. ${ }^{39}$ However, this constitutive practice is far from easy. This section shows that to successfully convey a particular symbolic image takes a lot of effort,

32 In a longer historical perspective, of course, non-state diplomatic actors are by no means a new phenomenon. For instance it was custom that major corporations acted as foreign policy organs of their home state in many of the imperial adventures.

33 R. Adler-Nissen, 'Late Sovereign Diplomacy', The Hague Journal of Diplomacy, 4:2 (2009), pp. 12141.

34 F. Mérand, European Defence Policy, p. 89.

35 Ibid.

36 F. Mérand, 'Pierre Bourdieu and the Birth of European Defense', Security Studies, 19 (2010), pp. 34274.

37 K. E. Smith, European Union Foreign Policy in a Changing World (Cambridge: Polity Press, 2008), pp. 3-9.

38 From a legal perspective, the EEAS is an institutional hybrid, which, in coming years, is likely to grow into a supranational diplomatic service - much like a Commission DG; B. Van Vooren, 'A LegalInstitutional Perspective on the European External Action Service', Common Market Law Review, 48 (2011), pp. 457-502.

39 I. Manners, 'Symbolism in European Integration', Comparative European Politics, 9:3 (2011), pp. 243 68 . 
not least because the EU establishes itself in a field with the nation state's established and recognised monopolisation of symbolic power and authority. ${ }^{40}$

\section{Beyond traditional diplomacy?}

The High Representative Catherine Ashton believes that the EEAS represents a new phenomenon in the diplomatic world. Introducing her proposal for the establishment of EEAS on 25 March 2010, Ashton stated: 'the Treaty of Lisbon offers precisely the opportunity to build modern policy for the modern world - moving beyond traditional "diplomacy", ${ }^{41}$ In saying thus, she describes traditional foreign policy (and national diplomacy) as anachronistic, something that needs to be surpassed because it does not fit a modern world. Indeed, the EEAS is different from a typical foreign ministry. It merges pre-existing Commission and Council institutions and instruments (also some that are not traditionally part of a foreign ministry such as military crisis management, while leaving out others such as export promotion). This is why Bátora calls the EEAS an interstitial organisation - that is, an organisation emerging in interstices between various organisations. ${ }^{42}$ However, as the subsequent sections will demonstrate, the EU's diplomatic service will not easily transcend national diplomacy because of the symbolic power of the nation-state.

There is an intriguing ambivalence in Ashton's discourse on the EEAS, which illustrates Bourdieu's point that in order for a newcomer to establish itself in a field, it needs to buy into the field's established codes. ${ }^{43}$ Being recognised as 'genuine' diplomacy is crucial to the success of the EEAS. This is largely due to the role still played by the nation-state in distributing diplomatic status and prestige, a power that reaches beyond formally delegated competences.

According to Ashton, one of the greatest challenges facing the EEAS is how to make an EU delegation just as recognisable and recognised as a national embassy:

When you go into an embassy of a member state anywhere in the world, you know which country you are in. How will it be that when you go in to look up the External Action Service somewhere in the world, you'll know that you are with Europe? It's that feeling of 'this is what we do and this is what we do well'. ${ }^{44}$

Newcomers must inevitably situate themselves in relation to the history and established language of the field. Since 1983, the Commission has given its Head of Delegations a courtesy title of 'Ambassador' although it 'might ventilate diplomatic sensitivities present in both member states and third countries'. ${ }^{45}$ What confers the magical or ontological effectiveness upon an ambassadorial title, 'which like the signature of the fashion designer, can increase the value of the object upon which it

40 Part of this analysis is also covered in R. Adler-Nissen, 'European diplomats: State Nobility and the Invention of a New Social Group', in N. Kauppi and M. R. Madsen (eds), Transnational Power Elites: The New Professionals of Governance, Law and Security (London, Routledge, 2013), pp. 65-80.

41 C. Ashton, Proposal for the European External Action Service, Speech by EUHR Ashton (Brussels: European Commission, 2010), emphasis added.

42 See J. Bátora, 'The "Mitrailleuse Effect": The EEAS as an Interstitial Organization and the Dynamics of Innovation in Diplomacy', Journal of Common Market Studies, 51:4 (2013), p. 608.

43 P. Bourdieu, Outline of a Theory of Practice (Cambridge: Cambridge University Press, 1977), p. 170.

44 Ashton, quoted in S. O'Connor, 'The Accidental Diplomat', E!Sharp (January-February 2010), p. 14.

45 J. Wouters and S. Duquet, 'The EU and International Diplomatic Law: New Horizons?', The Hague Journal of Diplomacy, 7:1 (2012), p. 40. 
is affixed?'46 One senior diplomat notes that 'surely you couldn't do the job without the title', highlighting the importance of traditional diplomatic institutions for the practice of world politics. ${ }^{47}$

The national foreign service - with a Ministry for Foreign Affairs and a diplomatic corps - remains the recognised model for organised diplomacy. The reference to state language and symbols was evident when the EEAS was first discussed in the Convention on the Future of Europe in 2002-3. ${ }^{48}$ In Working Group VII on 'External Action', one of the hotly debated issues was the safeguarding national foreign policy competences and was mentioned in the resumes of all the meetings. Another related issue was the title for the head of EU's foreign policy. Proposals ranging from 'EU Minister of Foreign Affairs' and 'EU Foreign Secretary' to 'European External Representative' were debated. The prevailing view in the Convention was that the latter 'had the advantage of not corresponding to a title used at national level'. ${ }^{49}$ However, in the final version of the Constitutional Treaty, the High Representative was called 'Union Minister for Foreign Affairs', following a FrancoGerman suggestion, despite opposition from several conventionells. ${ }^{50}$ The Convention also discussed establishing a diplomatic service, replete with a diplomatic training academy. ${ }^{51}$

While debate largely took place in the Convention, it also led to a broader political debate. Not only the British, but also the French, Irish, German, and Polish Parliaments discussed the implications of an EU diplomatic service intensely, focusing on issues of national sovereignty and parliamentary control. ${ }^{52}$ More than 40 per cent of the (English-language) news coverage framed the EEAS in terms of a possible erosion of national sovereignty and diplomacy. ${ }^{53}$

Following the French 'non' and the Dutch 'nee' to the Constitutional Treaty in 2005, the treaty was reopened. A number of 'red lines' were pencilled in by the British government, underlining that foreign policy decisions require unanimity and that the EU's foreign policy 'does not affect the responsibilities of the Member States ... for the formulation and conduct of their foreign policy nor of their national representation in third countries and international organisations' ${ }^{54}$ These red lines led to what some observers refer to as cosmetic changes, hereunder returning from 'Union Minister' to 'High Representative'. In substance, no changes were made to the position. However, the title of the head of EU foreign policy was seen to be symbolically important and had been one of the more difficult concessions given by the British delegation. ${ }^{55}$ Already in the treaty negotiations, it was clear

\footnotetext{
46 P. Bourdieu, 'The Historical Genesis of a Pure Aesthetics', The Journal of Aesthetics and Art Criticism (1987), p. 203

47 Interview, Danish Ministry of Foreign Affairs, 5 November 2012.

48 See A. Bogandy, 'The European Constitution and European Identity: Text and subtext of the Treaty establishing a Constitution for Europe', International Journal of Constitutional Law, 3:(2-3) (2005), pp. 295-315.

49 Final report of WG VII, fn. 1.

50 Art I-27; K. Radtke, 'The EU's Common Foreign and Security Policy', p. 147.

51 WG VII, WD 55, by I. M. de Vigo, p. 6.

52 For an overview of the debates in the different members states, see 'Reviewing Member States' Commitment to the European External Action Service', EPIN Working Paper, no. 34 (2012).

53 LexisNexis search for 'European External Action Service' and 'Union Foreign Minister' in all (Englishlanguage) news stories from 2002-9.

54 Declaration 13.

55 See WG VII, WD 40 by P. Hain.
} 
that the debates over the diplomatic service involved a struggle to impose a legitimate vision of the EU and its foreign policy in relation to national foreign policy.

Following the Treaty's entry into force in 2009, intense political negotiations involving the High Representative, the European Parliament, Council and Commission began, resulting in a set of key decisions for the EEAS. ${ }^{56}$ These decisions partly addressed the extension of the domain of the EEAS's legitimate practices, but they did not resolve questions of training, recruitment, or whether the EU should play a bigger role in consular affairs. While much was left for later negotiations, the constitutional struggle resulted in a hybrid diplomatic body. It was built on existing Commission and Council structures, but shaped by the language of national diplomacy. ${ }^{57}$

The crucial change in the European field is thus not so much that the EU seeks to construct a common foreign policy; the crucial change lies in the creation of a new institution, the EEAS, entrusted with diplomatic tasks and, more importantly, symbolic functions that were hitherto reserved for states only.

\section{Relative positions and diplomatic capital: staff and missions}

The relative position of national diplomats (incumbents) and EU diplomats (newcomers) in the diplomatic field depends on the volume and type of capital to which they have access. Diplomatic capital has both material and symbolic properties. This section first accesses the relative size of the EEAS vis-à-vis the national foreign services before analysing disputes over consular affairs and the symbolic power attached to it.

More specifically, I compare the total number of staff from each member state with the number of EEAS staff. ${ }^{58}$ In subsequent sections, I discuss how the category 'diplomat' is part of the struggle over the EEAS. Here it covers staff in the capital/ headquarters and in the diplomatic missions, including local staff members. The figures represent a rough estimate since the classification of staff functions varies in the respective member states. It should be noted that most of the officials in the EU missions today are Commission staff from the environmental, development, and trade DGs.

As illustrated in Table 2, France and the UK have about three times as much staff as the EEAS. This is not trivial. It means that the EEAS is only equivalent to a medium-size member state, such as Belgium. It comes as no surprise, therefore, that one of the greatest challenges for the new EU diplomats is to gain the trust and respect of the larger member states, in particular France and the UK. ${ }^{59}$ Moreover, with lack of resources, including personnel, the EEAS has difficulties making an impact on the ground.

56 In particular the Council Decision establishing the organisation and functioning of the European External Action Service (2010/427/UE).

57 P. Petrov, K. Pomorska, and S. Vanhoonacker, 'Introduction: The Emerging EU Diplomatic System: Opportunities and Challenges after Lisbon', The Hague Journal of Diplomacy, 7 (2012), p. 2.

58 See R. Balfour and K. Raik (eds), The European External Action Service and National Diplomacies, EPC Issue Paper, no. 73 (March 2013); see also M. Emerson et al., Upgrading the EU's role as a global actor, Institutions, Law and the Restructuring of European Diplomacy (Brussels: CEPS, 2011).

59 D. Allen and M. Smith, 'Relations with the Rest of the World', Journal of Common Market Studies, Annual Review, 49 (2011), pp. 209-30. 


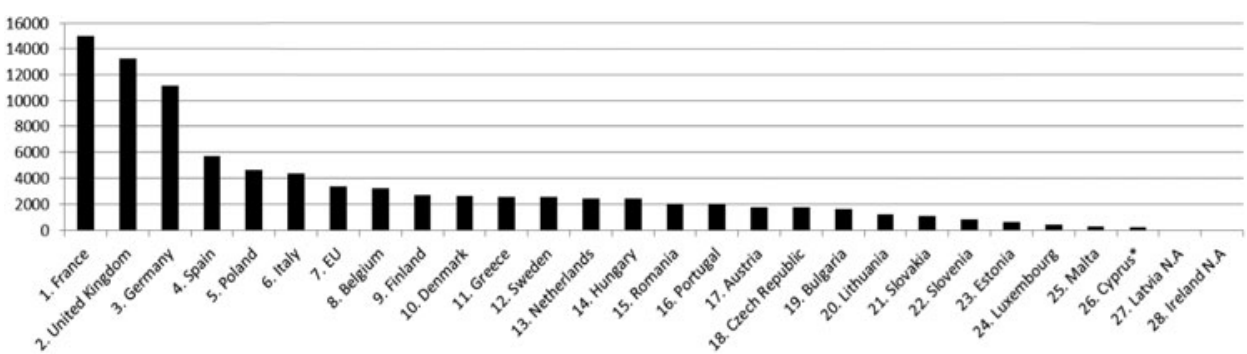

* This figure does not include local staff. Source: R. Balfour and K. Raik (eds), The European External Action Service, p. 167.

Table 2. Staff of the EU member states and of the EEAS

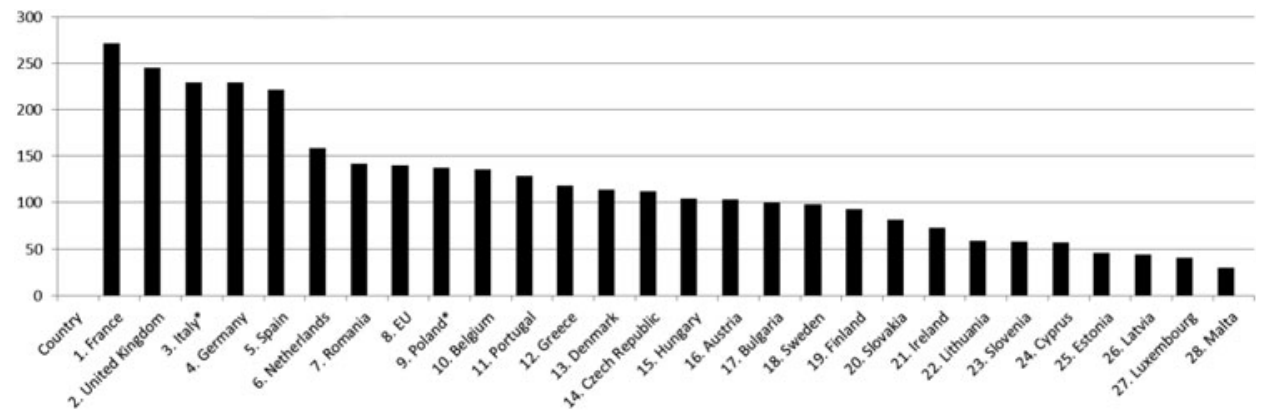

** These figures do not include cultural institutes abroad. Source: Balfour and Raik, The European External Action Service and National Diplomacies, p. 167.

Table 3. Diplomatic missions of the EU member states and the EEAS

In most cases, figures on staff include locally employed staff, but in some cases the number of locally employed staff was not available.

However, the number of staff does not necessarily tell us how the material dimension of diplomatic capital is distributed. It is equally important to examine how the EU is represented in the world. To explore this issue, I compare the number of diplomatic missions of each member state. Table 3 includes bilateral and multilateral embassies as well as consular missions (due to lack of detailed information from some foreign ministries, it is unfortunately not possible to distinguish between embassies and consulates). Thus for instance, when it comes to French missions, the exact number is 271 (of which there are 163 embassies, 92 consulates, and 16 representations to international organisations).

As Table 3 suggests, the EU fares better when it comes to diplomatic missions. Established by the European Commission over the last four decades, the EU has delegations scattered around the globe, not least because of the EU's trade policy, its leading role in distributing development aid, and the close links between the six 
founding members of the EU and their former colonies. ${ }^{60}$ It is worth noting that the EU's geographical representation is even more important given that the EEAS is only represented outside the EU whereas the numbers for member state missions also cover representations within the EU.

\section{Consular service: diplomacy for the people}

Yet the above comparison only provides a static picture of the distribution of human and material resources. What makes the EEAS so controversial is its potential to challenge the dominant position of national diplomats by pushing the boundaries of the state's reach and overtaking functions. Indeed, it is future growth, which makes some national diplomats anxious about cut-downs and replacement. As mentioned, it has been suggested that EU diplomats should not only be concerned with high politics, but also everyday consular service, that is, 'diplomacy for people'. Consular affairs relate to the protection of a country's own citizens in a foreign country. For years, the European Commission has attempted to convince member states to hand over consular affairs to the Commission's overseas delegations. ${ }^{61}$ Already today, European citizens have the right to be offered diplomatic and consular protection by other member states and to be treated in the same way as the nationals of other EU states if they find themselves in a third country where their own state is not represented. ${ }^{62}$ The (potential) role of the EEAS in providing consular protection has not been clearly defined. ${ }^{63}$ The Council Decision reads:

The Union delegations shall, acting in accordance with the third paragraph of Article 35 TEU, and upon request by Member States, support the Member States in their diplomatic relations and in their role of providing consular protection to citizens of the Union in third countries on a resource-neutral basis. ${ }^{64}$

The December 2011 EEAS evaluation report concluded that it is difficult to see how this objective could reasonably be achieved 'on a resource neutral basis'. Currently, the EEAS is not demandeur due to lack of resources and fear of burning its fingers of possible difficult cases. ${ }^{65}$

However, some member states and observers actively support the idea of letting the EEAS take over consular work, seeing this as a welcome support to national consular services in light of globalisation and the convergence of national interests. ${ }^{66}$ Moreover, for some small and medium-sized member states with few diplomatic

60 The EU's predecessor, the European Coal and Steel Community, opened its first mission in London in 1955, three years after non-EU countries began to accredit their missions in Brussels to the Community. Since then, the number of delegations has grown in numbers and tasks.

61 See A. M. Fernández, 'Consular Affairs in the EU: Visa Policy As a Catalyst for Integration?', The Hague Journal of Diplomacy, 1:3 (2008), p. 27. According to the Vienna Convention on consular relations of 1963 the functions of consular protection and assistance are the exclusive responsibility of states. See also the European Commission's communication Consular protection for EU citizens in third countries: State of play and way forward (COM(2011) 149).

62 Art 20, TEC.

${ }^{63}$ K Raik, 'Serving the citizens? Consular role of the EEAS grows in small steps', EPC Policy Brief (30 April 2013); Interview EEAS HQ, 14 May 2013; Interview, EU Delegation, 2 June 2013.

64 Art. 5-10.

65 Interview, EEAS HQ, 14 May 2013.

66 Emerson et al., Upgrading the EU's role as a global actor. 
representations, the EEAS provides new opportunities for diplomatic representation that would not otherwise exist. ${ }^{67}$ Also for the bigger member states, this may be attractive, as they currently have to deal with EU citizens whose countries of origin do not have embassies in their host nations. ${ }^{68}$ In this perspective, the EEAS is not seen as an alternative to national foreign services, but rather as an additional platform - just as the UN system or any other multilateral body.

So far, however, this overtaking of consular affairs has met too much opposition from a number of member states. Although they may see the practical usefulness of a greater role of the EU in consular affairs, decision-makers and parliamentarians worry about a 'substitution effect'. For instance, in 2010, during a House of Lords debate on the new diplomatic service, an anxious Lord Pearson of Rannoch asked: 'Can the noble Lord give us a clear assurance that there will be any British embassies left in 10 years' time?' His question was followed by a remark by Baroness Park of Monmouth:

However excellent the EU may be, it is not reasonable to expect a mixed EU representation to look after our national commercial interests and our national defence interests or indeed to handle the issue of passports and entry into this country. We shall need our own missions. I want to be assured that we shall not lose them in a splendid cost-cutting exercise by the Treasury. ${ }^{69}$

Also outside the UK, there is opposition. The Finish government reacted critically when Germany proposed to merge national embassies in Asia to make member state representation more cost-efficient. In Ireland, the government-ordered McCarthy report from 2008 on where to cut in public spending recommended shutting down Irish embassies and instead rely on EU's diplomacy, 'making the idea of separate Irish embassies representing Irish foreign policy a thing of the past'. ${ }^{70}$ In light of the austerity measures and cut downs in national foreign ministries, the state monopoly on providing consular services to nationals is likely to gradually disappear. If this happens, only national export and investment promotion and public diplomacy will remain responsibilities that rest solely with the national embassies. This helps explain why the EEAS is met with some concern in member states.

If EU delegations take over consular affairs, it will not only be a practical, but a highly symbolic move. The embassy is much more than a place of representation; it is the naturalisation of the state abroad and a reminder of our nationality through consular protection. As former US Ambassador to the UN Daniel Patrick Moynihan puts it, 'Embassies are unique architectural subjects. Perhaps no other public buildings are of such symbolic importance: much more than our domestic public buildings, their appearance establishes an image of the American government and people. ${ }^{71}$ Whereas companies and NGOs engage in both innovation and imitation of state diplomatic

67 See also I. Manners and R. Williams (eds), The Foreign Policies of the European Union Member States (Manchester: Manchester University Press, 2001), p. 262.

68 A Rettmann, 'France keen for EU diplomats to beef up security, consular services', EUObserver (20 March 2013); Interview, French Ministry of Foreign Affairs, 13 May 2013; see also K Raik, 'Serving the citizens?'

69 House of Lords, Main Chamber Debates 25 January 2010, No. 716: Part No. 31 (2010).

70 E. Delaney, 'Changes abroad will now reinvent diplomacy here', The Independent (13 November 2011).

71 Moynihan quoted in J. C. Loeffler, 'The Architecture of Diplomacy: Heyday of the United States Embassy-Building Program, 1954-1960', The Journal of the Society of Architectural Historians (1990), pp. 251-78. 
practices, they are often coopted by national foreign services. In contrast, if the EEAS performs symbolic functions such as political representation or takes over consular work, it questions more explicitly the distinctiveness of national foreign services.

To conclude, in material terms, the EEAS does not currently challenge national diplomacy, but this may change in the future, especially in light of the EU's impressive geographical representation. However, diplomatic capital is not only a question of material resources, it is also linked to belief and is the product of subjective acts of recognition.

\section{Classificatory struggles: defining the 'genuine' diplomat}

The categories used to perceive and appreciate diplomacy are always bound to historical context. Linked to a situated and historical universe, they make particular moves possible and make others seem out of place. The construction of the EEAS has produced a classificatory struggle over what it takes to be a 'genuine' diplomat in Europe today. I will illustrate this struggle by examining the skirmish that arose following the nomination of Catherine Ashton and the first Heads of Delegation.

\section{Ashton and the hysteresis effect}

What makes a 'genuine' diplomat? As Bourdieu argues, we 'must replace the ontological question with the historical question of the genesis of the universe', that is the diplomatic field within which the value of a diplomat is continuously produced and reproduced. In our case, the combatants are the national foreign services and the various groups of people that will end up in the EEAS. The struggle is crucial because the winner(s) will define the categories that give way to a distinction between 'true' diplomats and 'imitators'.

The choice of Ashton as head of the new service has generated much debate. Does she possess the right qualifications, does she have enough diplomatic capital? Romano Prodi, former president of the European Commission, described the choice of Ashton as 'mind-blowing'72 pointing to the fact that the former trade commissioner and member of Labour had no foreign policy experience.

Behaviour or practices become vulnerable to negative sanctions when individuals are faced with a situation or environment that is too remote from the one where they usually 'normally' fitted. This is what Bourdieu called the 'hysteresis effect'. Ever since her nomination, 'Ashton-bashing' has been increasing. This is the name that diplomats and officials use for the increasingly loud criticism that Ashton receives from member state capitals. ${ }^{73}$ Reports from the corridors of PSC meetings are all about the EEAS's 'poor preparations of foreign affairs minister's meetings', 'lack of in-depth knowledge', 'Ashton's paranoia' and need for more 'strategy and leadership'. ${ }^{74}$ National foreign services are increasingly undermining Ashton’s credibility

\footnotetext{
72 J. Leone, 'Divergent views over Van Rompuy and Ashton seem largely negative in Italy', EU-27 Watch, No. 9 (2010), available at: \{www.EU-27watch.org\}, accessed 20 November 2012.

73 Field notes.

74 Field notes, Interviews, EEAS HQ, 14 May 2013; EU Delegation, 10 June 2013.
} 
as a 'genuine' diplomat. Letters are circulated between foreign ministers, criticising Ashton and the EEAS. Former Belgian Foreign Minister Steven Vanackere went so far as to publically criticise the EEAS's analysis of the EU's strategic partners for a Foreign Affairs meeting, claiming that it was "very disappointing'. ${ }^{75}$ It appears that Ashton's habitus is in tensions with the field, consequently, she is perceived by national diplomats as a fish out of water. When Ashton moved into the Commission building (before the EEAS headquaters was ready), it was seen as a highly symbolic move by national diplomats. Now the EEAS has its own building with a top floor where, following Ashton's request, the corporate board is located in an open office, which is very non-MFA and not liked by national diplomats. ${ }^{76}$

To be clear, many foreign ministries genuinely support an integrated European foreign service. However, in engaging with Ashton and the EEAS they also reproduce their own experiences and understandings of diplomacy and hence the symbolic power of the state. The EU's diplomatic service makes national diplomats aware of their distinctiveness as national representatives. ${ }^{77}$ Notwithstanding the general respect for EU-related diplomatic work, there is - in all the member states - a profound scepticism when it comes to the EEAS. 'They are not real diplomats, they have no experience', a senior Head of Department in the Danish Ministry of Foreign Affairs explains, echoing similar statements by her colleagues in other EU member states. $^{78}$

What matters is not only whether Asthon and her staff really are competent, but the way in which national diplomats, the dominant players, imply that the state is the only source of diplomatic capital. Indeed, the value of Ashton as a diplomat owes to the structure of the diplomatic field. Not everyone is in a position to "command an open or tacit acceptance of his or her "power of naming", ${ }^{79}$ The foreign ministers from France, Germany, Italy, Belgium, Estonia, Finland, Latvia, Lithuania, Luxembourg, Netherlands, Poland, and Sweden clearly are in such a position. In December 2011, they circulated a non-paper accusing Ashton and the service of basic failings and dysfunctions. ${ }^{80}$ The attack pushed Ashton to thank the foreign ministers for their 'support' and 'input'. ${ }^{81}$ What some observers see as a question of personality takes place on the background of a struggle over the stakes in the European diplomatic field. In sum, 'diplomat' is not an individual property but rather 'an accomplishment resulting from collective sense-making', which means that a newcomer cannot simply designate herself as such but must receive the social categorisation 'diplomat' from other field participants. ${ }^{82}$

\section{Appointing heads of delegations}

The hysteresis effect is also at play at the level of Heads of Delegations. National diplomats have embarked on 'rearguard action to minimize the innovations of the

75 M. Labaki, 'Steven Vanackere critique Catherine Ashton', Le Soir (4 May 2011).

76 See Bátora, The 'Mitrailleuse Effect', p. 608.

77 Interview, Danish Ministry of Foreign Affairs, 10 August 2011.

78 Interview, Danish Ministry of Foreign Affairs, 6 May 2011; Interview, French Ministry of Foreign Affairs, 10 May 2011.

79 S. Guzzini, 'Power', in R. Adler-Nissen (ed.), Bourdieu in International Relations: Rethinking Key Concepts (London: Routledge, 2012), p. 83.

80 \{http://www.europarl.europa.eu/meetdocs/2009_2014/documents/afet/dv/201/201203/20120321_ nonpaperfms_en.pdf $\}$ accessed 20 November 2012.

81 Field notes.

82 DeClercq and Voronov, The Role of Domination, p. 800. 
Lisbon Treaty'. ${ }^{83}$ On 1 January 2010, all former 'European Commission delegations' were renamed 'European Union delegations' and were gradually upgraded into embassy-type missions invested with more power than the regular delegations. As mentioned, recruitment procedures were not settled during the treaty negotiations. Consequently, Ashton operated in an institutional vacuum when the first Heads of Delegations were appointed.

One of the most important EU delegations is the one in Washington DC. To the great surprise and anger of most capitals, Ashton appointed João Vale de Almeida, a former Head of Cabinet for José Manuel Barroso, as the new EU envoy - Head of Delegation - to the US. ${ }^{84}$ Because the post became vacant the before entry into force of the Lisbon Treaty, the Commission made the appointment according to previous guidelines. Carl Bildt, Sweden's foreign minister, immediately wrote to Catherine Ashton, complaining that member states were not consulted on the appointment of Almeida. ${ }^{85}$ In his letter, Bildt also recalled an 'understanding' reached in 2004 that the Washington job should go to 'a person with experience from a high political post'. In 2004, the Commission had appointed John Bruton, a former Irish prime minister, as its envoy to the US. Bildt was not only defending member state interests against Barroso's parachutage of his former chief of staff, he was also saying that Almeida lacked the diplomatic experience that comes with being a former prime minister or senior diplomat (an experience that a civil servant from the Commission arguably does not possess). ${ }^{86}$

The critique of Ashton's decision to appoint Almeida was not only about her failure to listen to the opinions of the member states. It also had to do with the very definition of what makes a good diplomat. Indeed, turf wars between the Commission and the member states cannot be understood without taking into consideration what is actually at stake in the diplomatic field in Europe. The Almeida incident highlighted the struggle over the kind of knowledge and resources that should confer power and status to the EEAS. Or as one diplomat explained, Barroso spotted this 'transititional phase to install Almeida, so that a Commission rather than a member state leader would be in charge'. ${ }^{87}$

In a 2010 letter addressed to Ashton, British Foreign Minister David Miliband and his Swedish counterpart Carl Bildt insisted that posts in the new diplomatic service be distributed in a transparent way, 'we will not achieve a step-change in the way we think without also changing some of the thinkers' ${ }^{88}$ The Polish Institute for International Affairs showed - unsurprisingly - that the Heads of Delegation were predominantly people with a long experience within the Commission. Consequently, the Heads of Delegation 'have noticeable knowledge of the procedures and organisational culture of the EU institutions, but [are] less familiar with the host countries

83 D. Spence, 'The Early Days of the European External Action Service', p. 116.

84 The nomination took place on 17 February 2010.

85 T. Vogel, 'Swedish Minister Criticises Washington Appointment', European Voice (22 February 2010).

86 The Almeida incident reflects Neumann's observation ('To Be a Diplomat', International Studies Perspectives, 6 (2005), pp. 72-93 that there is a status hierarchy between the 'hero script' and the 'bureaucratic script' in diplomacy. The hero is the active diplomat, making a difference abroad, while the bureaucrat is a civil servant in a dusty office 'back home'.

87 Interview, EEAS HQ, 14 May 2013.

88 D. Milliband and C. Bildt, letter to Baroness Ashton, 3 March 2010. 
and regions'. ${ }^{89}$ Once again, the langue used is that of lack of 'genuine' diplomatic experience.

The identification of lack of 'feel for the game' is important for our understanding of the EEAS. Following the nomination of Almeida, Ashton adjusted the way she appointed Head of Delegations. The need for experience from national foreign services is increasingly reflected in the way top positions are filled. In October 2010, former French Ambassador to the US, Pierre Vimont became secretary-general of the EEAS. Chief Operating Officer, David O'Sullivan, an Irish diplomat with a long career in Brussels, joined the leadership of the EEAS.

Ashton has also responded to concerns about recruitment of national diplomats, including those from new member states. In the 2012 rotation, five of the seven national diplomats appointed to management positions were from those member states, which joined the Union in 2004 and 2007. ${ }^{90}$ Today, about one-third of the management positions in Delegations are held by diplomats from national foreign ministries. However, to be recognised as a 'genuine' diplomatic service does not merely involve appointing more national diplomats, it concerns the adjustment between field and habitus.

\section{Towards a hybrid diplomatic culture: recruitment and careers}

The European diplomatic field is multinational; it draws on 27 different diplomatic traditions and recruitment systems. The understanding of the model diplomat is not necessarily the same in each member state. ${ }^{91}$ Within each national diplomatic field which is part of the power field of each member state - a relative distribution of capital is established. In France, the Ecole Nationale d'Administration (ENA) is a unique agency for training public service cadres, including those that end up working at the Quai d'Orsay. ${ }^{92}$ Depending on the particular national tradition, certain characteristics are rewarded (high class background), while others are punished (working class background). Such categories and silent hierarchies define the foreign service of each state. Most southern European states (for example, France, Spain, Italy, Greece, and Portugal) build on the concours tradition where the selection of diplomats is based on elaborate tests of knowledge, combining multiple choice, essays, and oral presentations. In contrast, in the Netherlands, Ireland and the UK, recruitment is based on psychometric and problem-solving tests where general knowledge plays a lesser role. ${ }^{93}$ Scandinavia, Germany, and Austria tend to combine the two traditions.

Yet national foreign services are only partly self-referring. As Cross notes with regard to intra-EU diplomacy:

\footnotetext{
89 R. Formuszewicz and J. Kumoc, 'The Practice of Appointing the Heads of EU Delegations in the Wake of Council Decision on the European External Action Service', Report of the Polish Institute of International Affairs (2010), p. 27.

90 'High Representative Catherine Ashton appoints 17 new Heads and Deputy Heads of Delegation', 16 May 2012, A 228/12

91 V. Karyagin, 'The Diplomatic Service: Yesterday, Today, Tomorrow', International Affairs, 12:40 (1994), pp. 32-44.

92 P. Bourdieu, La Noblesse d'Etat.

93 Respective webpages of the mentioned MFAs, Interview, German Ministry of Foreign Affairs, 15 May 2013 .
} 
Internal diplomacy has worked well in large part because of the similarities in the ways member-states select and train their diplomats. Diplomats typically come from the same top universities, they tend to share a similar social background, and they undergo the same type of formal and on-the-job-training. ${ }^{94}$

Moreover, the EU member states have developed common ideas about what constitutes a good diplomat, which postings are most prestigious, etc. ${ }^{95}$ For instance, a posting in the Permanent Representation in Brussels is regarded as a high-status post, increasing your diplomatic capital. To be COREPER ambassador gives a great deal influence and expertise, even superseding the position of ambassador to the US. 96

Traditionally, diplomats see themselves as responsible for promoting, for example, Sweden, France, Italy, and Poland. They have different 'minds of state'. This is not likely to change. Yet with the establishment of the EEAS, Sweden, France, Italy, and Poland have to recruit personnel from their own ranks to promote European interests in the EEAS. In principle, at least one third of all staff will come from the member states. This was one of the major results that were achieved following the difficult EEAS negotiations. As of June 2012 the share of member state diplomats has reached 27 per cent. ${ }^{97}$

Agents arriving in positions via different trajectories bring with them features of their distinct habitus. On 1 January 2011, the first employees were permanently transferred to the EEAS. 585 posts were transferred from the Commissions External Relations DG (which ceased to exist); 93 from the Commissions Development DG (the remainder of which merged into Development Cooperation DG); 436 from the Commission delegations; and 411 from the Council of the European Union. These joined with the 118 new employees - primarily from the member states - to create a staff of 1,643 on the day of transfer. Today, the EEAS has reached approximately 3,400 employees.

Following the formal construction of the EEAS, a recruitment system has been set up with assessment centres that pre-select candidates. Diplomats in the member states have generally been critical towards the slowness of the recruitment processes, which is largely due to lack of resources in the EEAS and the fact that recruitment is one of the most hotly debated issues. While the member states may propose their own candidates, the EEAS makes the decision on whom to appoint.

The drafters of the Council Decision found it necessary to write a characteristic EU compromise in Art 6(6): 'All appointments in the EEAS shall be based on merit and on the broadest possible geographical basis. The staff of the EEAS shall comprise a meaningful presence of nationals from all the Member States' (emphasis added). The former British foreign secretary indirectly recognised this when asked whether the recruitment would be based on merit or national quota:

\footnotetext{
94 M. K. Cross, 'Building A European Diplomacy: Recruitment and Training to the EEAS', European Foreign Affairs Review, 16:4 (2011).

95 F. Mérand, European Defence Policy Beyond the Nation State.

96 Interview, Danish Ministry of Foreign Affairs, 6 May 2011; Interview French Ministry of Foreign Affairs, 10 May 2011.

97 R. Balfour and K. Raik (eds), The European External Action Service and National Diplomacies, p. 170.
} 
It is very important indeed that appointments should be made through a transparent procedure and be based on merit, not nationality ... We will not want this to be on a traditional concours system ... We need the right skills and experience for the job. For example, the Chinese may need to have an EU Head of Delegation that has a strong knowledge of the region and even speaks Mandarin if he wants to have the maximum impact. ${ }^{98}$

Referring indirectly to the FCO recruitment procedures, the British foreign secretary clearly distanced himself from the types of merits that counts in the Commission system (or some of the other national diplomatic traditions). ${ }^{99}$

Another, partly related, worry concerns the EEAS's neutrality. Instead of representing the whole Union, it is feared that the EEAS will be controlled by one of the larger member states. French media, for instance, regularly suggest that France loses power to the UK in the new diplomatic service. ${ }^{100}$ There have also been concerns, notably in leaked German foreign policy documents, that the British dominate the whole structure of the EEAS. ${ }^{101}$ It is believed that Ashton is open to influence from London and that there are a large number of British staff in high-ranking positions already waiting to take on the top jobs in the EEAS. ${ }^{102}$ Yet among the four members in the EEAS corporate board and the seven managing directors, two are British, one is French, and one is German. The others are from other member states. The question of national balance is sensitive, but it is not the most important issue when it comes to the EU's diplomatic service. What is really at issue is the struggle of the EEAS to be seen as a competent and legitimate diplomatic body.

While member states compete between themselves, they increasingly also position themselves, collectively, against the EEAS. For instance, they criticise the balance between seconded national diplomats and those from EU institutions, and what they see as the continued dominance of Commission officials. ${ }^{103}$ Meanwhile Commission officials find that the member states are engaged in a 'hostile take-over'. ${ }^{104}$

One seconded national diplomat in a Middle Eastern EU Delegation explains it characteristically:

I have a different mentality. I see things differently than my colleagues who are old DG Relex and Council secretariat people. Due to my training in a national foreign ministry, I share knowledge with my colleagues as much as possible, while my Commission colleagues operate with an inside-the-box thinking and clearly demarcated areas of responsibility. When classic administrators are put together with strategic policy-makers, it limits our agenda-setting possibility. ${ }^{105}$

In sum, diplomats in the EU member states see themselves as sharing a particular professional culture: They are arguably trained to be 'strategic', to 'share knowledge', to follow a 'political line'. ${ }^{106}$ This culture does not include the civil servants from the Commission; they have different dispositions, loyalties, and experiences. ${ }^{107}$ Commission officials have entered the EU institutions through the EU concours system. They

98 House of Lords, Main Chamber Debates 25 January 2010.

99 Interview, UK Foreign and Commonwealth Office, 13 November 2011; Interview, French Ministry of Foreign Affairs, 10 May 2011.

100 J. Quatremer, 'The European Foreign Office', Libération (14 January 2011).

101 A. Rettman, 'Germany attacks UK over EU diplomatic service', EUobserver (1 March 2010).

102 Ibid.

103 Interview, Polish Ministry of Foreign Affairs, 10 March 2011.

104 Commission official, quoted in D. Spence, 'The Early Days of the European External Action Service', p. 120.

105 Interview, EU Delegation, 2 June 2013.

106 Ibid., 4 June 2013

107 Interview, EEAS HQ, 31 October 2011. 
compete for top positions within the Commission DGs in different ways than national diplomats compete to be posted to the most prestigious capitals.

\section{The diplomatic exchange rate}

The European diplomatic field is an area where possessors of different types of capital compete over different principles of recognition and privilege. At stake in these struggles is the relative value and strength of the capital possessed by the rival groups. Figuratively speaking, this value is settled by the going exchange rate for various forms of diplomatic capital. In the diplomatic field, the state has hitherto 'exercised a power over other species of capital ... and particularly over their rate of exchange'. ${ }^{108}$

One may consider the relative value and potency of different kinds of diplomatic capital (for example, traditional embassy work vs. experience from the EEAS). Would a national diplomat serving the EEAS for a couple of years return home with more or less diplomatic capital? While the Permanent Representations in Brussels is generally regarded a stepping stone (and a lot of hard work) for ambitious and striving diplomats, it is less certain that EEAS gives the same kind of recognition. Italy's Foreign Minister Franco Frattini writes:

These EU diplomats, who will return to their national foreign offices when their EEAS mandate expires, will be advocates of 'communitarising' training initiatives at home, helping their own administrations to better understand how the EU now works on the international stage. ${ }^{109}$

This requires, however, that EEAS experience be welcomed at home. Clearly, there is (still) no naturalisation of the categories and cognitive schemes produced by the EEAS.

Seen from the perspective of the national career diplomat, the EEAS poses a number of difficult questions relating to the symbolic power of the state. Would a career in the EEAS enhance your status? Since the EEAS is yet untested and its future success unknown, diplomats hesitate to opt for EEAS positions, as this move may prove detrimental to their future career. ${ }^{110}$ To acquire a dominant position in the field, the EEAS needs to be able to guarantee that when national diplomats as well as Council and Commission civil servants participate in the European diplomatic experiment, they will not lose 'market value' but keep or even improve their distinctions and privileges.

Interestingly, from a Commission perspective, a similar dynamic is at work. Previously, the Commission officials working at the delegations (typically from DG Relex) were certain to get a job afterwards and could finally advance to become Head of Delegation - or even more prestigiously - Area Boss. ${ }^{111}$ With the EEAS, however, such a career prediction becomes more tentative. Will the Commission official be able to continue his or her career - return to the Commission, possibly in

\footnotetext{
108 P. Bourdieu and L. Wacquant, An Invitation to Reflexive Sociology, p. 114.

109 'The European External Action Service: a look into EU diplomat training', European View, 9:2 (2010), pp. 219-27.

110 Interview, EU delegation, 10 June 2013.

111 Interview, EEAS HQ, 21 October 2011.
} 
another DG after serving in the EEAS? This has been one of the questions bothering EU civil servants; they wonder what will happen to them if they remain within the EEAS system. ${ }^{112}$ Hence, the three groups - Commission officials, Council officials, and national diplomats - share the same concern: How can I keep my status and prestige when returning home (to a national headquarter or Brussels)?

The creators of the new diplomatic service are conscious of the importance of careers and status and struggle to ensure that seconded staff from the member states has the same:

opportunities, rights and obligations (including functions, responsibilities, promotion, pay, leave and social benefits) as those of staff coming from the two other sources of origin. ${ }^{113}$

By doing so, they also hope to cultivate 'a common diplomatic culture', as one diplomat involved in the negotiations explains. ${ }^{114}$ As Ashton explains:

Ultimately this is all about people. Our staff is our most precious resource. We must make sure that they feel confident with the new structures. I will also see to it that colleagues from Member-States can find their place quickly in the EEAS and enrich it with their experience. ${ }^{115}$

In more general terms, the establishment of the EEAS is accompanied by a sort of reflective return by the producers of their own production in the diplomatic field. As one EEAS diplomat notes: 'Pursuing a career in the EEAS is only attractive if it gives prestige.' 116 This is where observers and field members point to the possible socialisation effects of a European diplomatic academy. ${ }^{117}$ As Bourdieu argued, systems of training and recruitment provide more than a curriculum of standardised substantive knowledge to students; they also introduce and naturalise fundamental categories of perception, which then shape how people understand society and their place within it. ${ }^{118}$ To repeat Ashton's words, this is indeed all about people and the meaning they confer to institutions such as the EEAS.

EU-level diplomacy relies on national foreign policy elites to succeed. ${ }^{119}$ Somewhat paradoxically then, in actively sanctioning what it means to be a 'genuine' diplomat, national diplomats may end up supporting the European diplomatic experiment. This has important implications. First, it would be a mistake to see the EEAS as radically different from a national diplomatic service in that it draws upon the very same categories that it seeks to transcend. The diplomatic field is made up by agents - field incumbents and newcomers alike - who contribute to the construction and reproduction of the field by struggling to maintain or gain more power in it. ${ }^{120}$ Thus, the EU's new diplomats may be more likely to function as agents of reproduction than subversion. Second, the EEAS leads to adjustment of dispositions and position-takings of national diplomats and Commission officials. In short, the

112 Ibid., 4 September 2011.

113 Presidency, 'Presidency Report'.

114 Interview, Danish Ministry for Foreign Affairs, Copenhagen, 14 April 2010.

115 C. Ashton, Proposal for the European External Action Service.

116 Interview, EEAS HQ, 8 May 2012.

117 See S. Duke, 'Diplomatic Training and the Challenges Facing the EEAS', The Hague Journal of Diplomacy, 7:1 (2012), pp. 95-114.

118 P. Bourdieu, 'Rethinking the State: Genesis and Structure of the Bureaucratic Field', in G. Steinmetz (ed.), State/Culture: State Formation after the Cultural Turn (Ithaca, NY: Cornell University Press, 1999).

119 Bátora, "The "Mitrailleuse Effect",

120 DeClercq and Voronov, The Role of Domination. 
transformation of diplomacy in Europe may result not only from the successful contestation of the field's dominant views by new actors such as the EEAS, but also from endogenous change, as invoked by some of the field incumbents. European foreign ministries may begin to innovate as part of the struggle for dominance.

\section{Conclusion}

A range of different processes, commonly known as globalisation, multilateralisation, and privatisation challenge national diplomacy. Yet to a large degree diplomacy still takes place within a field of rules and roles established over hundreds of years where states officially communicate with each other. We should thus avoid looking at new diplomatic actors in isolation, and instead ask how they adapt, transform or undermine this field. Existing analyses of 'new diplomacy' have limitations, which have worked against the development of more nuanced understandings of the evolution of diplomacy. One limitation concerns an overemphasis on material and institutional capacities, often at the expense of understanding the manifold cultural and social sources and effects of power. Thus, we are either presented with the rather ahistorical argument that new actors on the diplomatic scene will never be effective because states remain dominant (in terms of military or institutional capacities) or we are led to the conclusion that new actors will replace the national foreign services because of globalisation and growing interdependence. The problem is that we learn little about the relative significance of different diplomatic groups and we learn even less about how the new diplomats fight for recognition and legitimacy in a highly structured diplomatic field. Moreover, we lose sight of the counter-strategies adopted by the national foreign services.

This article began by drawing attention to an apparent puzzle: Why is the EU's External Action Service met with such anxiety when it is only the equivalent of a foreign service of medium-sized member state? This article has shown that a central, yet understudied, element in the struggle over the EU's new diplomatic service concerns symbolic power. Drawing on Bourdieu's sociology, I have then argued that the EU's diplomatic service challenges the meta-capital of the state, that is, its ability to monopolise symbolic power. I have demonstrated that the EEAS's current size hardly represents a threat to the national diplomatic services. Although the new diplomatic service has an impressive geographical representation compared to most member states, the size of its staff is equal to Belgium's foreign service. Indeed, the issue is more about future growth, which makes national services anxious about cutdowns and replacement. I have analysed the struggle to define the 'genuine' diplomat through what might at first appear as rather mundane issues of career patterns, training, recruitment policy and professional privileges. It is not so much the formal competencies or material resources of the EEAS that challenges the state; its challenge relies on its ability to accumulate symbolic power.

Alternative explanations for the struggle over the EEAS are possible. From an institutional perspective, the foreign minister letters to Ashton merely represent attempts to improve an unsatisfying situation, which may be solved in a few years. Institutional turf-wars, lack of resources, unclear command structures, mistrust between Commission and seconded national diplomats and low morale are to be expected. 
Yet this does not explain the intensity of the engagement by member states in questions about competences, titles such as 'Union Foreign Minister', consular affairs, recruitment, training, etc.

Cases such as the EEAS are ideal for exploring the dynamics through which specific international practices become naturalised, because it is precisely in moments of contestation over the boundaries of legitimate state practice that the historical contingency of the state's symbolic power is exposed. The main analytical benefit is that we can address the way in which the EEAS short-circuits the distinctions and individual dispositions that uphold a state-centric diplomatic system. 'Ashton-bashing' is not just a question of personality, but also an instance of hysteresis.

Europe is likely to see the emergence of a hybrid form of diplomacy. Paradoxically, if EU diplomats become successful foreign policy players, it will be because of the engagement of national foreign ministers. Rather than seeing the EU constructing wholly autonomous structures, the Union's own diplomacy largely depends on the traditional 'state nobility' in the 27 foreign services commuting to Brussels also because one third of the staff comes from the member states. For this hybrid diplomacy to develop, the EEAS needs to accumulate the kind of symbolic power hitherto reserved for national state bureaucracies. This does not mean that the EU will become a state, but it will involve a change in the established and recognised definition of the 'genuine' diplomat in Europe. To be recognised as a 'genuine' diplomatic services requires more than appointing national diplomats, it concerns the adjustment between field and habitus.

A focus on symbolic power resituates conventional approaches to the study of diplomacy, sovereignty, and the transformation of world politics. In their book on the diplomatic corps, Sharp and Wiseman conclude that 'the world primarily constituted as and by a society of states remains a critical anchor of all the other organizing principles in terms of what we think about social life'. ${ }^{121}$ However, this role as anchor depends on the state - and its diplomats - being able to remain the 'central bank for symbolic credit'. While the state currently enjoys ontological priority, rival ways of organising political life are emerging. Given the focus of much IR research with exposing the demise of state sovereignty through globalisation and other processes, this article is critical in highlighting the symbolic nature of these processes. While we may all agree that new actors have gained a more prominent position in world politics, scholars still need to explain the processes through which they become authoritative relative to the state. A non-state actor might challenge certain parameters of the diplomatic field, but not threaten the fundamental features that allow states to sanction misbehaviour. In short, newcomers do not necessarily perform as agents of change.

More broadly then, the application of Bourdieu's theory to the study of international relations can help expose power struggles inherent to the emergence of new actors and practices. This perspective may contribute to the practice turn in IR, ${ }^{122}$

121 P. Sharp and G. Wiseman, 'Conclusion: The Diplomatic Corps' Role in Constituting International Society', in P. Sharp and G. Wiseman (eds), The Diplomatic Corps as an Institution of International Society (Houndsmills: Palgrave, 2007), p. 276.

122 See, for example, I. B. Neumann, 'Returning Practice to the Linguistic Turn: The Case of Diplomacy', Millennium, 31:3 (2002), p. 639; E. Adler and V. Pouliot, 'International Practices', International Theory, 3:1 (2011), pp. 1-36, V. Pouliot, International Security in Practice: The Politics of NATORussia Diplomacy (Cambridge: Cambridge University Press, 2010). 
which has been criticised for overlooking power. Indeed a practice approach should not 'obscur[e] the broader context in which practices occur.' ${ }^{\prime 23}$ Be they legal, cultural, financial or military, practices are always situated in and shaped by a structured social space. Thus, it is not an individual action or property that makes a practice 'diplomatic'; rather it is an honour or measure of prestige granted by the field. Diplomacy, as all other social fields, always has a symbolic dimension and those that master this dimension will dominate the field. 